University of Nebraska - Lincoln

DigitalCommons@University of Nebraska - Lincoln

2012

\title{
A functional description of CymA, an electron-transfer hub supporting anaerobic respiratory flexibility in Shewanella
}

\author{
Sophie J. Marritt \\ University of East Anglia \\ Thomas G. Lowe \\ University of East Anglia \\ Jordan Bye \\ University of East Anglia \\ Duncan G. G. Mcmillan \\ University of Leeds \\ Liang Shi \\ Pacific Northwest National Laboratory, liang.shi@pnl.gov \\ See next page for additional authors
}

Follow this and additional works at: https://digitalcommons.unl.edu/usdoepub

Part of the Bioresource and Agricultural Engineering Commons

Marritt, Sophie J.; Lowe, Thomas G.; Bye, Jordan; Mcmillan, Duncan G. G.; Shi, Liang; Fredrickson, James K.; Zachara, John M.; Richardson, David J.; Cheesman, Myles R.; Jeuken, Lars J. C.; and Butt, Julea N., "A functional description of CymA, an electron-transfer hub supporting anaerobic respiratory flexibility in Shewanella" (2012). US Department of Energy Publications. 188.

https://digitalcommons.unl.edu/usdoepub/188

This Article is brought to you for free and open access by the U.S. Department of Energy at DigitalCommons@University of Nebraska - Lincoln. It has been accepted for inclusion in US Department of Energy Publications by an authorized administrator of DigitalCommons@University of Nebraska - Lincoln. 


\section{Authors}

Sophie J. Marritt, Thomas G. Lowe, Jordan Bye, Duncan G. G. Mcmillan, Liang Shi, James K. Fredrickson, John M. Zachara, David J. Richardson, Myles R. Cheesman, Lars J. C. Jeuken, and Julea N. Butt 


\title{
A functional description of CymA, an electron-transfer hub supporting anaerobic respiratory flexibility in Shewanella
}

\author{
Sophie J. MARRITT*, Thomas G. LOWE*, Jordan BYE*, Duncan G. G. McMILLAN†, Liang SHIł, Jim FREDRICKSON‡, \\ John ZACHARA $\ddagger$, David J. RICHARDSON*, Myles R. CHEESMAN*, Lars J. C. JEUKEN $\dagger$ and Julea N. BUTT*1 \\ ${ }^{*}$ Centre for Molecular and Structural Biochemistry, School of Chemistry and School of Biological Sciences, University of East Anglia, Norwich NR4 7TJ, U.K., † Institute of Membrane \\ and Systems Biology, Centre for Molecular Nanoscience, School of Physics and Astronomy, University of Leeds, Leeds LS2 9JT, U.K., and †Pacific Northwest National Laboratory, \\ Richland, WA 99352, U.S.A.
}

\begin{abstract}
CymA (tetrahaem cytochrome $c$ ) is a member of the NapC/NirT family of quinol dehydrogenases. Essential for the anaerobic respiratory flexibility of shewanellae, CymA transfers electrons from menaquinol to various dedicated systems for the reduction of terminal electron acceptors including fumarate and insoluble minerals of $\mathrm{Fe}(\mathrm{III})$. Spectroscopic characterization of CymA from Shewanella oneidensis strain MR-1 identifies three lowspin His/His co-ordinated $c$-haems and a single high-spin $c$ haem with $\mathrm{His} / \mathrm{H}_{2} \mathrm{O}$ co-ordination lying adjacent to the quinolbinding site. At $\mathrm{pH} 7$, binding of the menaquinol analogue, 2-heptyl-4-hydroxyquinoline- $N$-oxide, does not alter the midpoint potentials of the high-spin (approximately $-240 \mathrm{mV}$ ) and low-spin (approximately $-110,-190$ and $-265 \mathrm{mV}$ ) haems that appear biased to transfer electrons from the high- to lowspin centres following quinol oxidation. CymA is reduced with
\end{abstract}

menadiol $\left(E_{\mathrm{m}}=-80 \mathrm{mV}\right)$ in the presence of $\operatorname{NADH}\left(E_{\mathrm{m}}=-320\right.$ $\mathrm{mV})$ and an NADH-menadione (2-methyl-1,4-naphthoquinone) oxidoreductase, but not by menadiol alone. In cytoplasmic membranes reduction of CymA may then require the thermodynamic driving force from NADH, formate or $\mathrm{H}_{2}$ oxidation as the redox poise of the menaquinol pool in isolation is insufficient. Spectroscopic studies suggest that CymA requires a non-haem co-factor for quinol oxidation and that the reduced enzyme forms a 1:1 complex with its redox partner $\mathrm{Fcc}_{3}$ (flavocytochrome $c_{3}$ fumarate reductase). The implications for CymA supporting the respiratory flexibility of shewanellae are discussed.

Key words: cytochrome, electron paramagnetic resonance (EPR), electron transfer, magnetic circular dichroism (MCD), mineral respiration, quinol dehydrogenase.

\section{INTRODUCTION}

The Shewanella genus of $\gamma$-proteobacteria comprises a diverse group of facultative anaerobes [1]. Their ability to couple the oxidation of various carbon sources to the reduction of a broad range of terminal electron acceptors imparts a respiratory flexibility that allows colonization of varied, and changeable, marine and freshwater environments. Shewanella oneidensis strain MR-1 is the most extensively characterized of the shewanellae. It can use $\mathrm{O}_{2}$, fumarate, nitrate, thiosulfate, sulfite, elemental sulfur and trimethylamine $N$-oxide as terminal electron acceptors. These substrates enter the periplasm where their reduction is catalysed by dedicated enzymes homologous with well-characterized reductases found in many proteobacteria. However, S. oneidensis MR-1 is also capable of using particulate DMSO and the $\mathrm{Fe}(\mathrm{III})$ and $\mathrm{Mn}$ (III/IV) contained in oxide and phyllosilicate minerals as terminal electron acceptors. Reduction of these particulates occurs in the extracellular matrix catalysed by novel multihaem cytochromes whose structural and biochemical properties are beginning to emerge [2-6]. Electrons are delivered to the extracellular matrix from the periplasm by a porincytochrome complex that spans the outer membrane and has a biochemistry of significant biotechnological impact. The activity of the complex can be harnessed to pass electrons to the anode of microbial fuel cells and to facilitate the bioremediation of contaminated sediments by converting soluble radionuclides such as $\mathrm{U}(\mathrm{VI})$ and $\mathrm{Tc}(\mathrm{VII})$ into reduced less-soluble forms $[1,7]$.
Regardless of the nature and location of the terminal electron acceptor, redox cycling of $\mathrm{Q}$ (quinone) and its two electron reduced form $\mathrm{QH}_{2}$ (quinol) in the cytoplasmic membrane is key to respiratory energy conservation in S. oneidensis MR-1 [8-10]. Electrons from the oxidation of organic electron donors drive the reduction of $\mathrm{Q}$ to $\mathrm{QH}_{2}$ after which these electrons are directed to the periplasm through the action of $\mathrm{QH}_{2}$ dehydrogenases such as CymA (tetrahaem cytochrome $c$ ). CymA is a member of the NapC/NirT family of $\mathrm{QH}_{2}$ dehydrogenases and essential for the respiratory reduction of nitrate, nitrite, fumarate, DMSO, soluble complexed forms of $\mathrm{Fe}$ (III) and extracellular particulate substrates [11-15]. These enzymes, which in proteobacteria are more phylogenetically widespread than the cytochrome $b c_{1}$ complex, possess a single $\mathrm{N}$-terminal transmembrane helix with a globular haem-binding domain that protrudes into the periplasm for interaction with terminal reductases. At present, the only structures available for NapC/NirT homologues are of the homodimer $\mathrm{NrfH}$ (cytochrome $c$ nitrite reductase small subunit) in the $\mathrm{QH}_{2}$-nitrite oxidoreductase complex $(\mathrm{NrfH})_{2}(\mathrm{NrfA})_{4}$ from Desulfovibrio vulgaris [16,17]. Haem I is located in the globular domain in proximity to the $\mathrm{QH}_{2}$-binding site and haems II and III are positioned to relay electrons from haem I to the point of contact with the NrfA nitrite reductase at haem IV (haems are numbered in order of the $\mathrm{CxxCH}$ binding motifs in the primary structure). The axial ligands to haems II and III are provided by two histidine ligands as is typical for multihaem cytochromes; however, haems I and IV have unusual axial ligation. Haem I

Abbreviations used: CymA, tetrahaem cytochrome $c$; DDM, dodecyl maltoside; Fcc ${ }_{3}$, flavocytochrome $c_{3}$ fumarate reductase; HQNO, 2-heptyl-4hydroxyquinoline-N-oxide; LB, Luria-Bertani; LMCT, ligand-to-metal charge-transfer; MALDI-TOF-MS, matrix-assisted laser-desorption ionization-timeof-flight MS; MCD, magnetic circular dichroism; menadione, 2-methyl-1,4-naphthoquinone; NaHepes, sodium salt of Hepes; NrfH, cytochrome $c$ nitrite reductase small subunit; $\mathrm{Q}$, quinone; $\mathrm{QH}_{2}$, quinol; $\mathrm{SHE}$, standard hydrogen electrode.

1 To whom correspondence should be addressed (email j.butt@uea.ac.uk). 
is penta-co-ordinate with proximal ligation by methionine rather than the usual histidine from the $\mathrm{CxxCH}$ haem-binding motif. The proximal ligand of haem IV is histidine from its $\mathrm{CxxCH}$ binding motif. However, the distal ligand is provided by lysine from another subunit, namely, the NrfA nitrite reductase.

The specificity of the $\mathrm{QH}_{2}$ dehydrogenase-reductase partnership exemplified by NrfHA is typical for pathways dependent on NapC/NirT family members that can be characterized solely by their genomic context [18-22]. In contrast, cymA is an orphan gene in S. oneidensis MR-1 that is expressed constitutively, but up-regulated when fumarate or an electrode serve as the terminal electron acceptor [11,23,24]. Transient formation of CymA-reductase complexes would facilitate the distribution of electrons from $\mathrm{QH}_{2}$ to various terminal electron acceptors such that covalent linkage between CymA and its redox partners seems unlikely. Certainly Shewanella frigidimarina CymA, like other NapC/NirT family members and in contrast with $D$. vulgaris $\mathrm{NrfH}$, can be purified in the absence of a terminal reductase suggesting that association with the periplasmic redox partner is not essential for stability [25-28].

Given the high sequence identity, typically $>73 \%$, displayed by CymA within the clade of Shewanella it is likely that these enzymes have similar structures and mechanisms for $\mathrm{QH}_{2}$ oxidation. Accordingly, the haems in the soluble globular domain of $S$. oneidensis MR-1 CymA and the full-length CymA from $S$. frigidimarina have midpoint potentials $\left(E_{\mathrm{m}}\right)$ between approximately +10 and $-260 \mathrm{mV}$ compared with SHE (standard hydrogen electrode) [26,29,30]. Spectroscopic analysis of $S$. frigidimarina CymA by Richardson and colleagues led to the proposal that each of the four haems have His/His ligation [26]. There are sufficient conserved histidine residues in the sequence to accommodate this pattern of ligation, but it has significant implications with regard to presenting a unified mechanism for $\mathrm{QH}_{2}$ oxidation across the NapC/NrfH family. Whereas $\mathrm{QH}_{2}$ oxidation is proposed to occur at penta-co-ordinate haem I with methionine ligation in $\mathrm{NrfH}$, it would appear to be catalysed by a hexa-co-ordinate His/His-ligated haem in CymA. Alternatively $\mathrm{QH}_{2}$ binding to CymA may induce a change of ligation at the $\mathrm{QH}_{2}$ oxidizing haem perhaps driving it to a penta-co-ordinate form. The latter scenario may change the spin-state and/or reduction potentials of the CymA haems and so the framework in which $\mathrm{QH}_{2}$ oxidation is considered.

In Shewanella sp. during anaerobic growth when the activity of CymA is critical the $\mathrm{QH}_{2}$ pool is dominated by menaquinols and methylmenaquinols $\left(E_{\mathrm{m}} \sim-80 \mathrm{mV}\right)[15,31,32]$. Consequently, we have applied a combination of spectroscopic methods and potentiometric titration to resolve structural, thermodynamic and kinetic properties of $S$. oneidensis MR-1 CymA in the absence and presence of two menaquinol analogues, namely, menadiol and HQNO (2-heptyl-4-hydroxyquinoline- $N$-oxide). We have also assessed the extent of CymA reduction that can be achieved in the absence and presence of a periplasmic redox partner $\mathrm{Fcc}_{3}$ (flavocytochrome $c_{3}$ fumarate reductase). The results of the present study allow us to present a revised functional description of CymA that is relevant to the anaerobic respiratory flexibility of Shewanella sp.

\section{EXPERIMENTAL}

\section{Purification of CymA and $\mathrm{FCC}_{3}$ from S. oneidensis MR-1}

CymA was purified from $S$. oneidensis MR-1 as described previously for the purification of the enzyme from $S$. frigidimarina [26], with cultures grown micro-aerobically in LB (Luria-Bertani) medium at $\mathrm{pH} 7.5$ supplemented with $50 \mathrm{mM}$ DL-lactate. The low yields of CymA from these cells prompted construction of an overexpression strain as described below. Soluble $\mathrm{Fcc}_{3}$ was purified from $S$. oneidensis MR-1 as described previously [33].

\section{Construction of an overexpression system for CymA}

The cymA gene (locus tag SO4591) of S. oneidensis MR-1 was cloned using the protocol described previously for overexpression of Shewanella multihaem cytochromes [34,35]. Briefly, the gene was amplified by PCR with primers 5'-CACCTAAGAAGGAGATATACATCCCATGAACTGGCGTGCACTATTTAAAC-3' (cymA 1-25 bp; insertion sites are in bold) and 3'-GAGTGGGGATAGGTTTTCCT-5' (cymA 541-561 bp). The PCR product was cloned into a protein expression vector derived from pBAD202/D-TOPO (Invitrogen) to create the plasmid pLS167. Following verification by sequencing, pLS167 was transformed into $S$. oneidensis MR-1 cells to create an MR-1 strain LS447 maintained on LB medium plates containing $50 \mu \mathrm{g} \cdot \mathrm{ml}^{-1}$ kanamycin.

\section{Purification of recombinant CymA}

Recombinant CymA was purified from membranes of $S$. oneidensis MR-1 strain LS447 grown at $30^{\circ} \mathrm{C}$ in Terrific Broth adjusted to $\mathrm{pH} 7.5$ and containing $50 \mu \mathrm{g} \cdot \mathrm{ml}^{-1} \mathrm{kanamycin}$. Micro-aerobic growth was achieved by shaking 1 litre batch cultures in 2 litre conical flasks at $180 \mathrm{rev} . / \mathrm{min}$. Overexpression of cymA was induced by the addition of $1 \mathrm{mM}$ arabinose during exponential growth at an attenuance of $\sim 0.7$ at $600 \mathrm{~nm}$. Cells were harvested after a further $18 \mathrm{~h}$ of growth by centrifugation at $15000 \mathrm{~g}$ for $30 \mathrm{~min}$ at $4{ }^{\circ} \mathrm{C}$, washed twice and resuspended in $100 \mathrm{mM}$ NaHepes (sodium salt of Hepes) pH 7.5 buffer. Cell lysis was performed by two passages through a French Press at a pressure of 1000 psi $(1 \mathrm{psi}=6.9 \mathrm{kPa})$. Membranes were pelleted by ultracentrifugation at $4000 \mathrm{rev} . / \mathrm{min}$ at $4{ }^{\circ} \mathrm{C}$ with a Beckman $45 \mathrm{Ti}$ rotor in $100 \mathrm{mM}$ NaHepes (pH 7.5), homogenized and washed twice in $100 \mathrm{mM}$ NaHepes buffer containing $100 \mathrm{mM} \mathrm{NaCl}, 1 \mathrm{mM}$ EDTA and protease inhibitors (Roche).

Membrane proteins were solubilized in $50 \mathrm{mM}$ NaHepes (pH 7.5) containing $2 \mathrm{mM}$ EDTA, protease inhibitors and $1 \%$ (w/v) DDM (dodecyl maltoside) for $16 \mathrm{~h}$ at $4{ }^{\circ} \mathrm{C}$, and insoluble material was removed by ultracentrifugation. Purification of CymA was then monitored by SDS/PAGE and electronic absorbance spectroscopy with all steps performed at $4{ }^{\circ} \mathrm{C}$. Solubilized membrane proteins at approximately $20 \mathrm{mg} \cdot \mathrm{ml}^{-1}$ were diluted 10 -fold in $20 \mathrm{mM}$ Tris/ $\mathrm{HCl}$ and $1 \mathrm{mM}$ EDTA $(\mathrm{pH} 8.8)$ and stirred into a slurry of DEAE Sepharose CL-6B anion-exchange medium (GE Healthcare). CymA was extracted by batch elution with increasing concentrations of $\mathrm{NaCl}$ in $20 \mathrm{mM}$ Tris/ $\mathrm{HCl}$ (pH 8.8) containing 0.05\% DDM. Elution with $130 \mathrm{mM}$ $\mathrm{NaCl}$ isolated a fraction containing the majority of CymA that was concentrated by ultrafiltration over an Amicon YM30 membrane and then dialysed overnight against $20 \mathrm{mM}$ NaHepes, $\mathrm{pH}$ 7. DDM was excluded from the dialysis buffer because the micelle size $(50 \mathrm{kDa})$ and slow rate of detergent exchange between micelle and solution will result in the majority of DDM being retained inside the dialysis tubing with CymA. The dialysed CymA was loaded on to a Q-Sepharose anion-exchange column pre-equilibrated with $20 \mathrm{mM}$ NaHepes ( $\mathrm{pH} 7$ ) containing $0.05 \%$ DDM. The column was washed with 10 column vol. of $20 \mathrm{mM}$ NaHepes (pH 7) containing $0.05 \%$ DDM and then 20 mM NaHepes ( $\mathrm{pH} 7$ ) containing $0.05 \%$ DDM and $50 \mathrm{mM} \mathrm{NaCl}$. CymA samples with the lowest quinone content as evidenced by the ratio of 
electronic absorbance at $270 \mathrm{~nm}$ (quinone) compared with $407 \mathrm{~nm}$ (haem) eluted with $20 \mathrm{mM}$ NaHepes containing $0.05 \%$ DDM and $130 \mathrm{mM} \mathrm{NaCl}$. These samples were then concentrated and subjected to size-exclusion chromatography on a HiLOAD S200 Superdex column (GE Healthcare) in $25 \mathrm{mM}$ NaHepes containing $0.05 \%$ DDM yielding CymA with a typical absorbance ratio, $A_{407 \mathrm{~nm}} / A_{275 \mathrm{~nm}}$, of 4 .

\section{Biochemical analyses}

All of the SDS/PAGE analyses were performed using the Laemmli discontinuous buffer method with $15 \%$ polyacrylamide separating gels. Gels were developed for protein detection by Coomassie Brilliant Blue staining and for haem detection using the haem-linked peroxidase activity [26]. Immunoblotting for the V5 tag used the alkaline phosphatase method for detection of the relevant antibodies. MALDI-TOF-MS (matrix-assisted laser-desorption ionization-time-of-flight MS) analysis was performed at the Institute of Food Research and John Innes Centre Proteomics Facility (Norwich, U.K.). The predicted masses of the tryptic digests were determined using the ExPASy PeptideMass online software (Swiss Institute of Bioinformatics). N-terminal sequencing was performed at the Protein and Nucleic Acid Chemistry Facility at Cambridge University (Cambridge, U.K.). The haem content was determined using the pyridine haemochrome method [36] giving a value for the moral absorption coefficient at $407 \mathrm{~nm}$, $\varepsilon_{407 \mathrm{~nm}}$, of $380 \pm 38 \mathrm{mM} \mathrm{m}^{-1} \cdot \mathrm{cm}^{-1}$ for the oxidized protein assuming four haems per CymA monomer. Electronic absorption spectra were recorded on a JASCO V650 spectrophotometer. EPR spectra were recorded using a spectrometer comprising an ER-200D electromagnet and microwave bridge interfaced to an EMX control system (Brüker, Spectrospin) and fitted with a liquid helium flow cryostat (ESR-9, Oxford Instruments) and a dualmode X-band cavity (Brüker, type ER4116DM).

To assess the Q content of CymA fractions eluted from the HiLOAD S200 Superdex column they were subject to solvent extraction (twice) with aqueous methanol/acetone $(50 / 50 \mathrm{v} / \mathrm{v})$ and petroleum ether $(60 / 40 \mathrm{v} / \mathrm{v})$ using the method of Myers and Myers [15]. Briefly, this involved stirring $0.5 \mathrm{ml}$ of protein sample, typically $0.1-0.5 \mu \mathrm{M}$ CymA, with $3 \mathrm{ml}$ of acetone/methanol for $30 \mathrm{~min}$ followed by the addition of $1 \mathrm{ml}$ of petroleum ether and stirring for $1 \mathrm{~min}$. After the aqueous and organic layers had separated the Q-containing petroleum ether layer was pipetted off and evaporated under nitrogen gas. The $\mathrm{Q}$ extract was resuspended in $100 \mu \mathrm{l}$ of ethanol/methanol (50/50 v/v) and resolved by HPLC analysis with a reverse-phase C18 $(5 \mu \mathrm{m})$ column (dimensions $150 \mathrm{~mm} \times 4.6 \mathrm{~mm}$; Phenomenex) with ethanol $/ \mathrm{methanol}(50 / 50 \mathrm{v} / \mathrm{v})$ as the mobile phase. The eluate was monitored by electronic absorbance at $248 \mathrm{~nm}, 270 \mathrm{~nm}$ and $290 \mathrm{~nm}$ to distinguish menaquinones (peak maxima at $248 \mathrm{~nm}$ and $270 \mathrm{~nm}$ ) from ubiquinones (290 nm peak maximum). Comparison with the elution profile of standard solutions of menaquinone-7 $\left(\varepsilon_{248 \mathrm{~nm}}=18.9 \mathrm{mM} \mathrm{mM}^{-1} \cdot \mathrm{cm}^{-1}\right.$; Wako Chemicals $)$ identified this as the major Q in the sample (retention time $30 \mathrm{~min}$, flow rate $0.3 \mathrm{ml} \cdot \mathrm{min}^{-1}$ ).

\section{HQNO-binding assays}

Fluorescence-quench titrations were performed to determine the affinity of CymA for HQNO [37]. Experiments were carried out with CymA solutions of the desired concentration in $100 \mathrm{mM}$ Mops, $5 \mathrm{mM}$ EDTA and $0.05 \%$ DDM (pH 7) at room temperature $\left(20^{\circ} \mathrm{C}\right)$. HQNO ( $>99 \%$ purity; Enzo Life
Sciences) was added as aliquots from a stock solution of 100 , 250 or $500 \mu \mathrm{M}$ in ethanol/water $(30 / 70 \mathrm{v} / \mathrm{v})$. Fluorescence intensities were measured using an excitation wavelength of $341 \mathrm{~nm}$ and an emission wavelength of $479 \mathrm{~nm}$ using a Varian Cary Eclipse Fluorescence Spectrophotometer. Variation of fluorescence intensity $\left(F_{\text {obs }}\right)$ with HQNO concentration was fitted to eqn 1 that describes reversible binding of a single HQNO molecule to a single site on CymA [37]:

$$
\begin{aligned}
F_{\text {obs }}= & f_{\text {free }}\left[\mathrm{HQNO}_{\text {total }}\right]+\left(f_{\text {bound }}-f_{\text {free }}\right) \\
& \times\left(\mathrm{Q}-\sqrt{\mathrm{Q}^{2}-\left[\mathrm{CymA}_{\text {total }}\right]\left[\mathrm{HQNO}_{\text {total }}\right]}\right)
\end{aligned}
$$

with:

$\mathrm{Q}=\frac{1}{2}\left(\left[\mathrm{HQNO}_{\text {total }}\right]+K_{\mathrm{d}}+\left[\mathrm{CymA}_{\text {total }}\right]\right)$

and:

$\left[\mathrm{HQNO}_{\text {total }}\right]=\left[\mathrm{HQNO}_{\text {bound }}\right]+\left[\mathrm{HQNO}_{\text {free }}\right]$

where $f_{\text {bound }}$ and $f_{\text {free }}$ are the specific fluorescence of bound and free HQNO respectively, $K_{\mathrm{d}}$ is the dissociation constant for binding of HQNO, and CymA and the subscripts 'total', 'bound' and 'free' refer to total, bound and free forms of the molecule respectively.

\section{Potentiometric titration}

All experiments were performed using spectroelectrochemical cells employing a three-electrode configuration that allowed a defined voltage to be applied to the sample. Cyclic voltammetry and amperometry were performed with an Autolab PGSTAT12 potentiostat under the control of GPES software. Studies of CymA adsorbed on to mesoporous nanocrystalline $\mathrm{SnO}_{2}$ electrodes were performed using the spectroelectrochemical cells described previously [38]. Spectropotentiometric titration of CymA solutions monitored by MCD (magnetic circular dichroism) were typically performed with $10 \mu \mathrm{M}$ CymA in $20 \mathrm{mM}$ NaHepes and $100 \mathrm{mM} \mathrm{NaCl}(\mathrm{pH} 7)$ containing a mediator cocktail lacking Qs and their analogues that comprised $40 \mu \mathrm{M}$ each of: potassium ferricyanide $\left(E_{\mathrm{m}} \sim+0.42 \mathrm{~V}\right)$, ferrocene acetic acid $\left(E_{\mathrm{m}} \sim+0.36 \mathrm{~V}\right)$, diaminodurene $\left(E_{\mathrm{m}} \sim+0.25 \mathrm{~V}\right)$, dichlorophenol-indophenol $\left(E_{\mathrm{m}} \sim+0.22 \mathrm{~V}\right)$, phenazine methosulfate $\left(E_{\mathrm{m}} \sim+0.08 \mathrm{~V}\right)$, phenazine ethosulfate $\left(E_{\mathrm{m}} \sim+0.05 \mathrm{~V}\right)$, Methylene Blue $\left(E_{\mathrm{m}} \sim+0.01 \mathrm{~V}\right), \quad$ Nile Blue $\left(E_{\mathrm{m}} \sim-0.12 \mathrm{~V}\right)$, phenosafranine $\left(E_{\mathrm{m}} \sim-0.23 \mathrm{~V}\right)$, Neutral Red $\left(E_{\mathrm{m}} \sim-0.32 \mathrm{~V}\right)$, Benzyl Viologen $\left(E_{\mathrm{m}} \sim-0.35 \mathrm{~V}\right)$, Sulfonyl Viologen $\left(E_{\mathrm{m}} \sim-0.39 \mathrm{~V}\right)$ and Methyl Viologen $\left(E_{\mathrm{m}} \sim-0.44 \mathrm{~V}\right)$. Equilibration of the sample at desired potentials was achieved using a gold-mini-grid working electrode as described previously [38]. Room temperature MCD spectra were recorded in a magnetic field of 8 Tesla using a circular dichrograph, JASCO J-710, together with an Oxford Instruments split-coil superconducting magnet fitted with a $50 \mathrm{~mm}$ ambient temperature bore. All potentials are quoted compared with the $\mathrm{SHE}$ at $\mathrm{pH}$ 7.0.

\section{Assays of $\mathrm{QH}_{2}$ oxidation coupled with CymA reduction}

All of the sample manipulations were performed under strict anaerobic conditions in an $\mathrm{N}_{2}$-filled glove-box (atmospheric $\mathrm{O}_{2}<4$ p.p.m.). Solutions containing the desired concentrations of NADH, menadione (2-methyl-1,4-naphthoquinone), CymA, $\mathrm{Fcc}_{3}$ and fumarate in $20 \mathrm{mM}$ NaHepes and $0.5 \mathrm{mM}$ EDTA $(\mathrm{pH} 7)$ 
were stirred for $30 \mathrm{~min}$ in the glove-box prior to placing them in a 1-cm path-length cuvette that was subsequently sealed against the external atmosphere. The assay was initiated by the addition of Clostridium kluyveri diaphorase (Sigma-Aldrich) and the oxidation of NADH monitored by the decrease in absorbance at $340 \mathrm{~nm}$. Experiments to investigate the extent to which the CymA haems were reduced by $\mathrm{QH}_{2}$ were performed using a similar protocol, but excluding $\mathrm{Fcc}_{3}$ and fumarate. Electronic absorbance spectra were measured between $300 \mathrm{~nm}$ and $700 \mathrm{~nm}$. Concentrations of menadione were determined using $\varepsilon_{248 \mathrm{~mm}}=18.9 \mathrm{mM}-1 \cdot \mathrm{cm}^{-1}$. When concentrated solutions of menadiol were required these were produced by electrodic reduction of menadione in an electrochemical cell employing a three-electrode configuration and graphite working electrode.

\section{RESULTS}

\section{Expression, purification and catalytic activity of CymA}

The pBAD-TOPO expression vector that features an L-arabinose inducible promoter and fuses a V5-epitope and $\mathrm{His}_{6}$ tag to the Cterminus of the protein has been shown previously to produce Shewanella sp. strain ANA-3 CymA in the parent strain and to complement a cymA deletion strain [39]. Consequently this vector was employed to express $S$. oneidensis MR-1 cymA in the parent strain. Purification of recombinant CymA from $S$. oneidensis MR-1 membranes was achieved through a combination of anion-exchange and gel-filtration chromatographies since the protein did not bind avidly to metal-ion affinity columns. The resulting protein was judged to be greater than $90 \%$ pure from a combination of SDS/PAGE, MS, N-terminal sequencing and electronic-absorption spectroscopy. Native CymA of comparable purity was obtained from $S$. oneidensis MR-1 membranes by minor modification of a previously described protocol [26]. The electronic absorbance spectra, redox properties and catalytic activity of the recombinant and native proteins were indistinguishable as described below. However, the significantly higher yields of recombinant than native CymA allowed EPR and MCD spectroscopies to be employed for greater structural insight. Consequently the data presented below were collected from recombinant protein that for simplicity is termed CymA in the text below.

The $\mathrm{QH}_{2}$ dehydrogenase activity of purified CymA was investigated through a coupled assay that measured the loss of absorbance at $340 \mathrm{~nm}$ due to the NADH-dependent reduction of fumarate to succinate. The assay employed the sequential activities of diaphorase, as an NADH-Q oxidoreductase, CymA to oxidize $\mathrm{QH}_{2}$, and then the soluble fumarate reductase $\mathrm{Fcc}_{3}$ from S. oneidensis MR-1 to pass electrons from CymA to fumarate. A rate of $0.6 \pm 0.1 \mathrm{NADH}$ oxidized $\mathrm{min}^{-1}$. $\mathrm{CymA}^{-1}$ was measured on initiating the assay by the addition of diaphorase $(1.5 \mu \mathrm{M})$ to a solution containing $50 \mu \mathrm{M}$ NADH, $1.2 \mu \mathrm{M}$ menadione, $0.2 \mu \mathrm{M} \mathrm{CymA}, 1 \mu \mathrm{M} \mathrm{Fcc}$ and $1 \mathrm{mM}$ fumarate at $\mathrm{pH}$. The calculated rate value has been corrected for the background rate of NADH auto-oxidation, $0.05 \pm 0.01 \mu \mathrm{M}$ NADH oxidized. $\mathrm{min}^{-1}$, determined in control assays which contained menadione, $\mathrm{Fcc}_{3}$ and fumarate, but no CymA.

\section{Primary structure, electrophoretic profile and oligomeric state}

The theoretical peptide mass of recombinant CymA is $24.3 \mathrm{kDa}$ and for the holoprotein with four $c$-type haems inserted is $26.8 \mathrm{kDa}$. SDS/PAGE analysis of purified CymA visualized by Coomassie Brilliant Blue stain revealed a major band at approximately $24 \mathrm{kDa}$ corresponding to the predicted mass of

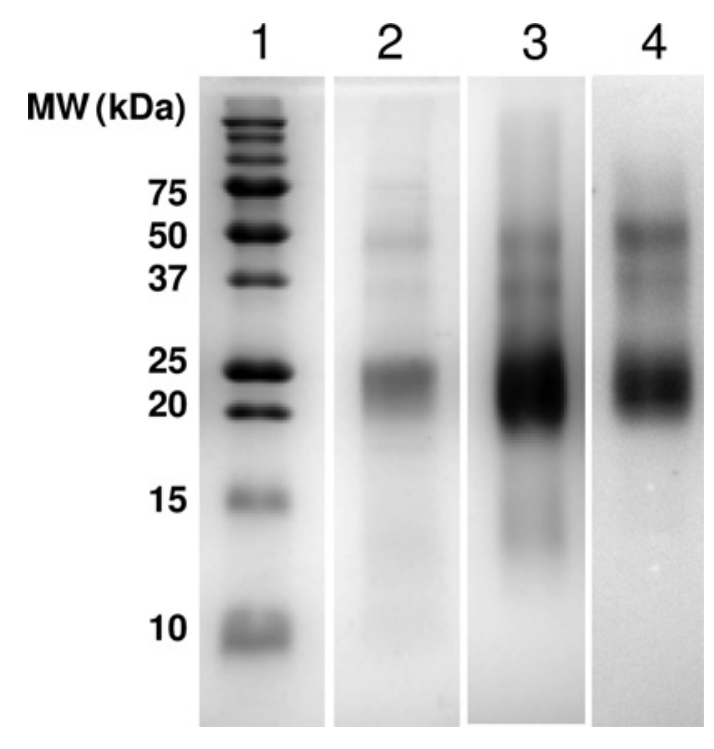

\section{Figure 1 SDS/PAGE of CymA}

Protein visualized by Coomassie Brilliant Blue stain (lane 2), haem stain (lane 3) and immunoblot against the anti-V5 epitope (lane 4). Molecular mass markers are shown for comparison (lane 1). Protein was loaded at $2 \mu \mathrm{g}$ for Coomassie Brilliant Blue staining, $0.5 \mu \mathrm{g}$ for haem staining and $0.8 \mu \mathrm{g}$ for the immunoblot.

the monomer (Figure 1). This was confirmed as CymA through $\mathrm{N}$-terminal sequencing that identified the predicted residues (MNWRA) and positive responses in immunoblots for the V5 epitope (Figure 1). Tryptic digest followed by MALDITOF-MS identified three fragments with the predicted peptide masses for CymA digestion products lacking covalently bound haem (Supplementary Table S1 at http://www.BiochemJ.org/ bj/444/bj4440465add.htm).

In addition to the band at approximately $24 \mathrm{kDa}$ identified by SDS/PAGE, minor bands were detected at approximately 40 and $50 \mathrm{kDa}$. All three of the bands stained positively for the presence of $c$-type haem using haem-linked peroxidase staining (Figure 1). The 40 and $50 \mathrm{kDa}$ bands were confirmed as CymA by positive staining in an immunoblot for the V5 epitope (Figure 1), and the fragmentation patterns following MS of tryptic digests. The higher-molecular-mass bands could arise from partially unfolded protein or oligomeric forms. Consequently dynamic light scattering and gel filtration were used to provide direct insight into the oligomeric state of native CymA in solutions containing approximately $0.05 \% \mathrm{DDM}$ as used throughout the present study. The mass of a DDM micelle is approximately $50 \mathrm{kDa}$ and this would rise to approximately $75 \mathrm{kDa}$ on inclusion of a CymA monomer and approximately $100 \mathrm{kDa}$ on inclusion of a CymA dimer. Dynamic light scattering of CymA $(80 \mu \mathrm{M})$ reported a hydrodynamic radius of $8 \mathrm{~nm}$, corresponding to a mass of approximately $95 \mathrm{kDa}$, with a polydispersity of $35 \%$ that is indicative of a sample of homogeneous size, shape and mass distribution. In gel-filtration chromatography, the DDMsolubilized CymA eluted as a single peak with an apparent molecular mass of approximately $130 \mathrm{kDa}$. Both results support the presence of a CymA dimer within the DDM micelle.

\section{Spectral properties}

The electronic absorbance spectrum of oxidized CymA in the visible region is dominated by features typical of low-spin $\left(S={ }^{1} / 2\right)$ ferric $c$-haems, namely, a Soret band with a maximum 


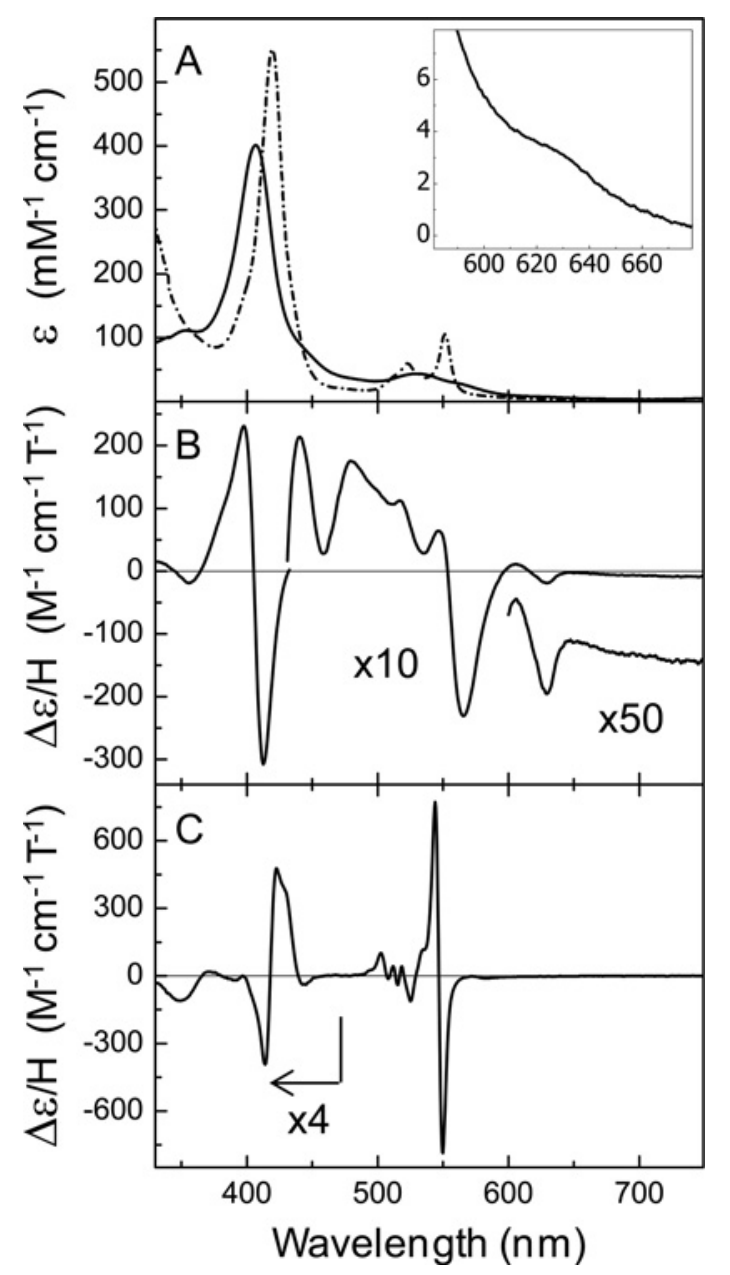

Figure 2 Spectroscopic characterization of CymA

(A) Electronic absorbance spectra for CymA oxidized (solid line) and fully reduced by dithionite (broken line). Inset, an expanded view of the spectrum of oxidized CymA between 580 and $700 \mathrm{~nm}$. MCD spectra measured at ambient temperature for oxidized (B) and fully dithionite reduced (C) CymA. In each case the buffer was $20 \mathrm{mM}$ Hepes at pH 7.0 containing approximately $0.05 \%$ DDM. For MCD of reduced CymA the enzyme was $10 \mu \mathrm{M}$ and for oxidized enzyme it was $20 \mu \mathrm{M}$ for the Soret region and $80 \mu \mathrm{M}$ for $450-800 \mathrm{~nm}$.

at $407 \mathrm{~nm}$ and a broad absorbance between 500 and $600 \mathrm{~nm}$ corresponding to the $\alpha / \beta$ bands (Figure 2A). However, closer inspection of the higher-wavelength region of the spectrum reveals a broad feature with a peak at $630 \mathrm{~nm}$. Such features typically arise from LMCT (ligand-to-metal charge-transfer) bands associated with high-spin $(S=5 / 2)$ ferric haems. They are more clearly visualized by MCD where their wavelength is diagnostic of the chemical nature of the axial haem ligands [40]. MCD of CymA presents a clear bisignate feature with a trough at $628 \mathrm{~nm}$ that is indicative of a histidine- or lysine-co-ordinated haem having water as the second axial ligand (Figure 2B). This feature has an intensity of $3 \mathrm{M}^{-1} \cdot \mathrm{cm}^{-1} \cdot \mathrm{T}^{-1}$ that compares with typical intensities of $1-4$ $\mathrm{M}^{-1} \cdot \mathrm{cm}^{-1} \cdot \mathrm{T}^{-1}$ per high-spin ferric haem and it lies in a spectral region that is free from contributions from low-spin haem [40]. At wavelengths below $600 \mathrm{~nm}$ the MCD of CymA is dominated by features characteristic of low-spin ferric $c$-haem with the most prominent of these in the Soret region having a peak-to-trough intensity of $540 \mathrm{M}^{-1} \cdot \mathrm{cm}^{-1} \cdot \mathrm{T}^{-1}$. For low-spin ferric haems the peak-to-trough intensity of the prominent Soret feature is typically $150 \pm 10 \mathrm{M}^{-1} \cdot \mathrm{cm}^{-1} \cdot \mathrm{T}^{-1}$ compared with a maximal intensity of $20 \overline{\mathrm{M}}^{-1} \cdot \mathrm{cm}^{-1} \cdot \mathrm{T}^{-1}$ for high-spin ferric haem [41]. Given these

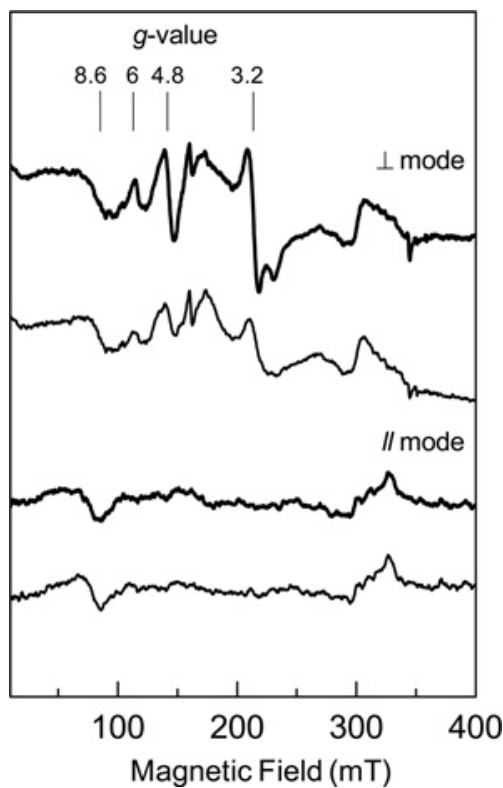

Figure 3 X-band EPR spectra for CymA with and without HQNO bound

Fully oxidized CymA ( $80 \mu \mathrm{M})$ in the absence (thick lines) and presence (thin lines) of HQNO $(270 \mu \mathrm{M})$ in $20 \mathrm{mM}$ Hepes and $0.05 \% \mathrm{DDM}$ at pH 7.0. Spectra were recorded at $10 \mathrm{~K}$ with $100 \mathrm{~mW}$ microwave power and modulation amplitude of 10 Gauss in the perpendicular mode (microwave frequency $9.7 \mathrm{GHz}$ ) and parallel mode $(9.4 \mathrm{GHz}$ ) as indicated.

reference intensities and a molar absorption coefficient at $407 \mathrm{~nm}$ of $380 \pm 38 \mathrm{mM}^{-1} \cdot \mathrm{cm}^{-1}$ for oxidized CymA, as described in the Experimental section, the MCD spectrum is consistent with the presence of one high-spin and three low-spin haems as the nearest integer values.

X-band EPR spectra of oxidized CymA in the perpendicular mode resolved prominent features with $g$ values of $\sim 8.6,4.8$ and 3.2 (Figure 3 ). The features at $g \sim 8.6$ and $\sim 3.2$, with the former retained in parallel mode, are typical of an integer spin species arising from a coupled high-/low-spin haem pair as seen in other multihaem cytochromes including the cytochrome $c_{\mathrm{m} 552}$ ubiquinone reductase purified from Nitrosomonas europaea in the absence of a periplasmic redox partner [27,42]. The signals between $g \sim 3$ and 5 may arise from exchange-coupled lowspin haems. The relatively sharp resonance with zero crossing at $g=4.8$ seen in the perpendicular mode EPR of CymA is unusual. However, it is also displayed by the NrfHA complexes of Wolinella succinogenes, Desulfovibrio desulfuricans and D. vulgaris where it was proposed to arise from spin-coupled haems in NrfH since it is absent from spectra of NrfA [43]. Significantly, there is no evidence for features attributable to the rhombic trios or large $g_{\max }$ signals that would typically arise from uncoupled low-spin ferric haem. The feature at $g \sim 6$ that arises from uncoupled high-spin ferric haem represents only a very small fraction of the protein concentration. When all features of the EPR spectrum are taken together it is apparent that the spins of all of the haems in oxidized CymA are electronically coupled and this conclusion is supported by the low intensity of the EPR features relative to the CymA concentration. Importantly the overall description of CymA as containing both low- and highspin ferric haems is consistent with that deduced from optical spectroscopies.

Dithionite reduction of CymA results in the appearance of maxima at 551.5, 520 and $420 \mathrm{~nm}$ in the electronic absorption spectrum that are typical for the $\alpha-, \beta$ - and Soret-features arising from reduced low-spin ferrous $c$-haem (Figure 2A). The MCD 
of dithionite-reduced CymA confirms the complete reduction of the haems since there is no indication of features typical of either low- or high-spin ferric haems (Figure 2C). Instead the spectrum is dominated by a sharp bisignate feature centred on $548 \mathrm{~nm}$ with a peak-to-trough intensity of $1400 \mathrm{M}^{-1} \cdot \mathrm{cm}^{-1} \cdot \mathrm{T}^{-1}$ arising from low-spin ferrous haem. The bisignate feature in the Soret region with a trough at approximately $443 \mathrm{~nm}$ and peak at approximately $430 \mathrm{~nm}$ of $90 \mathrm{M}^{-1} \cdot \mathrm{cm}^{-1} \cdot \mathrm{T}^{-1}$ is indicative of the presence of high-spin ferrous haem. The intensity at $430 \mathrm{~nm}$, arising from high-spin ferrous haems, is typically of the order of $100 \mathrm{M}^{-1} \cdot \mathrm{cm}^{-1} \cdot \mathrm{T}^{-1}$, whereas the peak-to-trough intensity of the bisignate feature centred on $552 \mathrm{~nm}$ arising from low-spin ferrous haem is typically of the order of $400 \mathrm{M}^{-1} \cdot \mathrm{cm}^{-1} \cdot \mathrm{T}^{-1}[38,44]$. The MCD intensity from the ferrous haems is, like that from the ferric haems, consistent with nearest integer values of one high-spin and three low-spin centres given the uncertainty in the molar absorption coefficient of CymA noted above.

\section{HQNO binding}

The $\mathrm{QH}_{2}$-binding affinity of oxidized CymA was measured using the menaquinol analogue HQNO since the fluorescence of the latter is quenched when it binds to a protein in the vicinity of a haem co-factor (see [39] and references therein). In the absence of CymA the intensity of fluorescence arising from HQNO increases in direct proportion to its concentration (Figure 4A). When HQNO is titrated into a solution of CymA this fluorescence is quenched until the binding sites become saturated (Figure 4A). Following this point the fluorescence increases in a linear manner reflecting the presence of free HQNO. The slope of the linear region of these plots decreases as the concentration of CymA increases. This is behaviour that has been noted in other studies, e.g. [37,39], and it results from non-specific quenching of the HQNO fluorescence that prevents the affinity of HQNO for a membrane protein being defined simply by titration of the protein into a solution of fixed HQNO concentration. Consequently, the data of Figure 4(A) were fitted to eqns (1)-(3) that describe reversible 1:1 binding of HQNO to CymA with $K_{\mathrm{d}}=0.5 \pm 0.3 \mu \mathrm{M}$.

When a 20-fold excess of HQNO was added to $20 \mu \mathrm{M}$ CymA such that essentially all of the enzyme had bound HQNO there was little change in the electronic absorbance spectrum through the Soret and $\alpha / \beta$ regions (Figure 4B). In contrast, a clear spectral change was noted between 550 and $700 \mathrm{~nm}$ that is most readily appreciated in the difference spectrum where the high-spin ferric haem charge-transfer band shifts to longer wavelength and narrows on HQNO binding (Figure 4B, inset). Thus HQNO binding perturbs the environment of the high-spin haem without changing the net spin states of the haems. This conclusion was confirmed by MCD where the binding of HQNO results in negligible change between 350 and $600 \mathrm{~nm}$ where the spectrum is dominated by contributions from low-spin ferric haem (Supplementary Figure S1, upper panel at http://www.BiochemJ.org/bj/444/bj4440465add.htm). In contrast, the charge-transfer band at $628 \mathrm{~nm}$ broadens reflecting an altered environment of the high-spin ferric haem. In agreement with these observations, the EPR of CymA with bound HQNO retains the feature at $g \sim 8.6$ arising from an exchange-coupled high-spin/low-spin haem pair and shows only subtle changes of intensity for some of the other spectral features (Figure 3). The MCD of dithionite-reduced CymA with HQNO bound was indistinguishable from that of the reduced enzyme in the absence of HQNO (Supplementary Figure S1, lower panel). Thus one high-spin and three low-spin haems are present in reduced HQNObound CymA as for the oxidized enzyme.
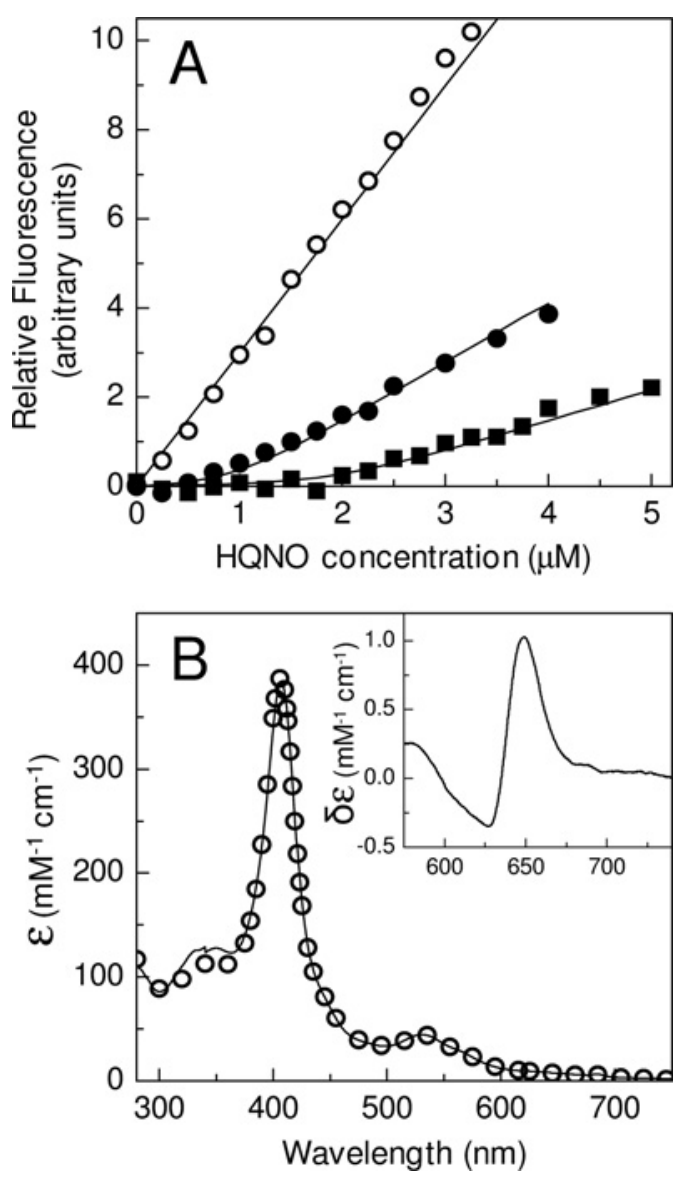

Figure 4 Optically monitored HQNO binding to CymA

(A) Representative HQNO fluorescence in the presence of $0(\bigcirc), 1(\mathbf{O})$ and $3(\boldsymbol{\square}) \mu \mathrm{M}$ CymA in $100 \mathrm{mM}$ Mops, $5 \mathrm{mM}$ EDTA and $0.05 \%$ DDM at pH 7.0. (B) Representative electronic absorbance spectra for $20 \mu \mathrm{M}$ CymA before $(\bigcirc)$ and after (solid line) the addition of $400 \mu \mathrm{M}$ HQNO in $20 \mathrm{mM}$ Hepes and $0.05 \% \mathrm{DDM}$ at pH 7.0. Inset: difference in the absorbance of HQNO-bound and HQNO-free CymA.

\section{Spectropotentiometry}

MCD most clearly resolves signals from both the low- and highspin states of the ferric and ferrous haems in CymA. Consequently, potentiometric titration monitored by MCD spectroscopy was employed in initial experiments to resolve the redox behaviour of CymA in the presence and absence of bound HQNO (Figures 5A and $5 B$ ). In both cases spectra typical of the fully oxidized enzyme were recorded at potentials above $0 \mathrm{mV}$. Samples poised below $-40 \mathrm{mV}$ displayed the sharp bisignate feature centred on $548 \mathrm{~nm}$ that is characteristic of low-spin ferrous haem. In contrast, the positive feature at $430 \mathrm{~nm}$ that is diagnostic of high-spin ferrous haem was detected only below $-150 \mathrm{mV}$. An MCD-compatible optically transparent thin-layer electrochemical cell was used to facilitate the collection of these data [45]. Nevertheless, full reduction of CymA in a practical timescale was prevented by the long equilibration times (typically $>30 \mathrm{~min}$ ) resulting from slow diffusion in DDM that were compounded if large changes in potential were applied to the sample. Consequently, the redox properties of the low-spin haems were quantified by normalizing the peak-to-trough MCD intensity of the feature at $548 \mathrm{~nm}$ to that displayed by fully dithionite-reduced CymA. A similar strategy was adopted to quantify reduction of the high-spin haem after accounting for changes in intensity at $430 \mathrm{~nm}$ due to the loss of signal from the low-spin ferric haems (Figure 5A). Plotting these 

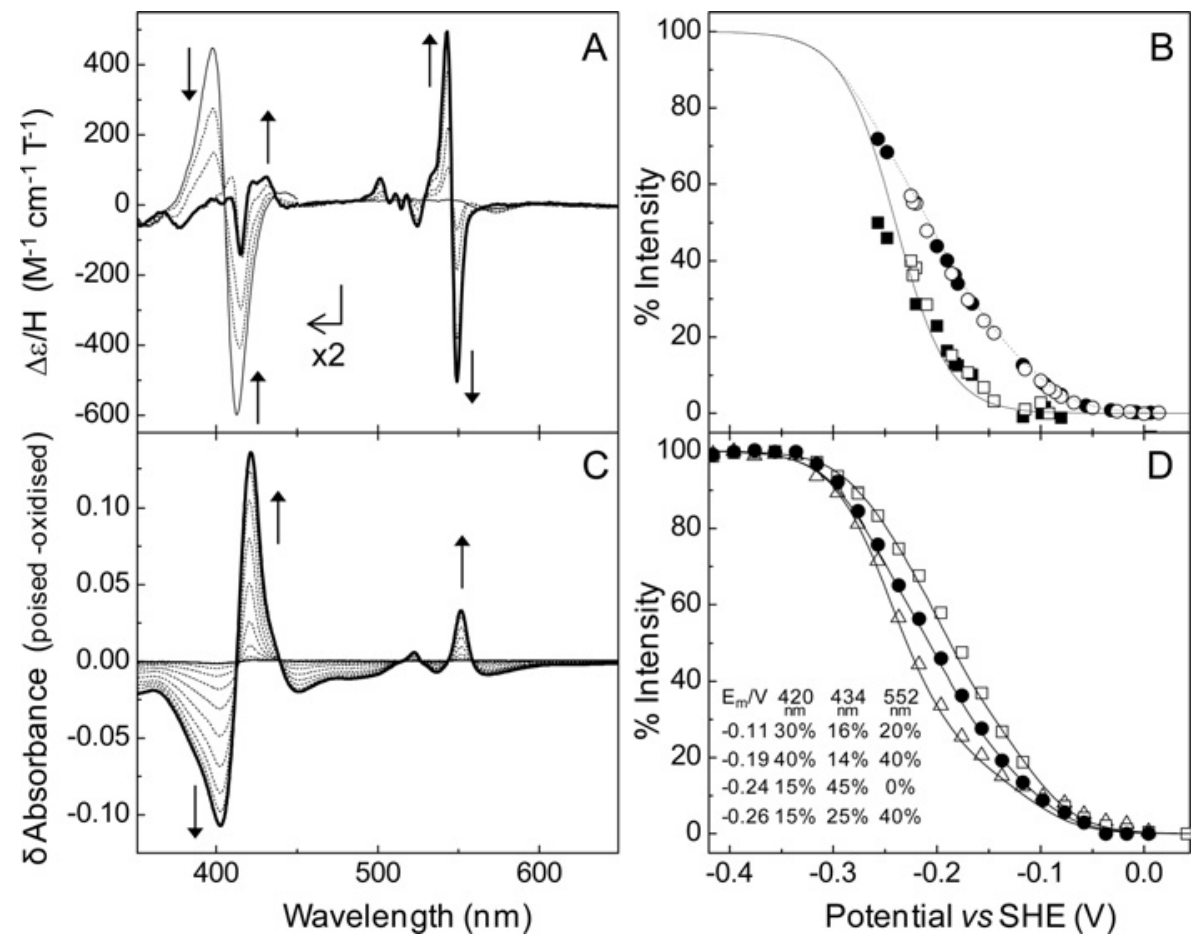

Figure 5 Spectropotentiometric titration of CymA

(A) MCD monitored potentiometry of CymA (10 $\mu \mathrm{M})$ in the presence of HQNO $(200 \mu \mathrm{M})$ in $20 \mathrm{mM}$ Hepes and $100 \mathrm{mM} \mathrm{NaCl}(\mathrm{pH} 7.0)$ and approximately $0.05 \%$ DDM. Spectra were recorded for the sample equilibrated at $0 \mathrm{~V}$ (thin solid line), $-0.12 \mathrm{~V},-0.17 \mathrm{~V},-0.22 \mathrm{~V}$ (broken lines) and $-0.26 \mathrm{~V}$ (heavy solid line). Arrows indicate the direction of spectral change on reduction. (B) The potential dependence of MCD intensity at $550 \mathrm{~nm}$ (circles) and $430 \mathrm{~nm}$ (squares) for CymA in the absence (open symbols) and presence (closed symbols) of HQNO. The intensity at each wavelength is plotted as a percentage of that displayed by fully reduced CymA (Figure 2C). The solid line describes Nernstian behaviour for a single $n=1$ centre with $E_{\mathrm{m}}=-0.24 \mathrm{~V}$. The broken line describes the sum of three Nernstian responses for $n=1$ centres contributing equally to the intensity change and having $E_{\mathrm{m}}$ values of $-0.11 \mathrm{~V},-0.19 \mathrm{~V}$ and $-0.265 \mathrm{~V}$. (C) Potentiometric titration of CymA adsorbed on $\mathrm{SnO}_{2}$ electrodes and equilibrated at potentials between $+0.04 \mathrm{~V}$ and $-0.4 \mathrm{~V}$ in $20 \mathrm{mM}$ Hepes and $100 \mathrm{mM} \mathrm{NaCl}(\mathrm{pH} 7.0)$. Data are plotted as the difference spectra, poised-minus-oxidized, arrows indicate the direction of spectral change on reduction. (D) Potential dependence of absorbance change at $420 \mathrm{~nm}(\square), 434 \mathrm{~nm}(\Delta)$ and $552 \mathrm{~nm}(\mathbf{\bullet})$. Lines show the sum of Nernstian behaviours for $n=1$ redox centres with $E_{m}=-0.11 \mathrm{~V},-0.19 \mathrm{~V},-0.24 \mathrm{~V}$ and $-0.26 \mathrm{~V}$ and the relative contributions indicated.

normalized signal intensities as a function of sample potential provided no evidence for a change in the redox properties of CymA on binding HQNO (Figure 5B).

CymA was adsorbed as an electrochemically active film on optically transparent mesoporous nanocrystalline $\mathrm{SnO}_{2}$ electrodes in order to gain an independent assessment of its redox chemistry over a wider potential window than accessible to the MCDcompatible cell (Figures 5C and 5D). Equilibration at any given potential was achieved within 5 min and electronic absorption spectroscopy of the film poised at potentials from +40 to $-400 \mathrm{mV}$ revealed the spectral changes anticipated for the transformation of fully oxidized to fully reduced CymA. These changes are readily visualized in difference spectra where the spectrum of fully oxidized CymA (poised at $+40 \mathrm{mV}$ ) has been subtracted from those of the sample poised at other potentials and where isosbestic points occur at 412, 439, 543 and $559 \mathrm{~nm}$ (Figure 5C). The absorbance at $552 \mathrm{~nm}$ arises solely from lowspin haem. There was no hysteresis in the potential dependence of this absorbance over multiple cycles of reduction and oxidation. Consequently it can be concluded that redox transformation of the three low-spin ferric haems is fully reversible.

The spectral changes in the Soret region contain information relating to the redox transformation of the high-spin haem in CymA. However, this information is superimposed on that from spectral changes that describe redox transformation of the lowspin haems. The spectral changes from the high-spin haems extend to slightly longer wavelengths (>approximately $420 \mathrm{~nm}$ ) than for their low-spin counterparts such that in favourable cases it is possible to clearly resolve redox transformation of low- and high-spin haems [38]; however, this is not the case for CymA. Consequently, a global analysis of the data at 552, 434 and $420 \mathrm{~nm}$ was performed to resolve $E_{\mathrm{m}}$ values for the one highspin and three low-spin haems (Figure 5D). It was assumed that each haem behaves as an isolated single electron $(n=1)$ centre described by the Nernst equation. The following constraints were also applied: (i) the absorbance changes at $552 \mathrm{~nm}$ must arise only from three low-spin haems; and (ii) the changes of absorbance at 420 and $434 \mathrm{~nm}$ must arise from one high-spin and three low-spin haems with the former making a more significant contribution to the magnitude of the spectral change at 434 than $420 \mathrm{~nm}$. This analysis resolved $E_{\mathrm{m}}$ values of $-110,-190$ and $-265 \mathrm{mV}$ for the low-spin haem and $-240 \mathrm{mV}$ for the high-spin haem, where all values are $\pm 30 \mathrm{mV}$ (Figure 5D). These $E_{\mathrm{m}}$ values provided a good description of the MCD monitored potentiometry where spectral features arising purely from both low- and high-spin haems are more readily revealed, as described above (Figure 5B).

\section{CymA reduction by $\mathrm{QH}_{2}$}

The low solubility of menaquinols in aqueous solution makes it difficult to design an experiment to confidently assess their ability to reduce DDM-solubilized CymA. Consequently, the reduction of CymA by $\mathrm{QH}_{2}$ was probed using menadiol, a water-soluble analogue of menaquinol. Menadione and menaquinone have comparable reduction potentials. By itself excess menadiol $(\times 30)$ 

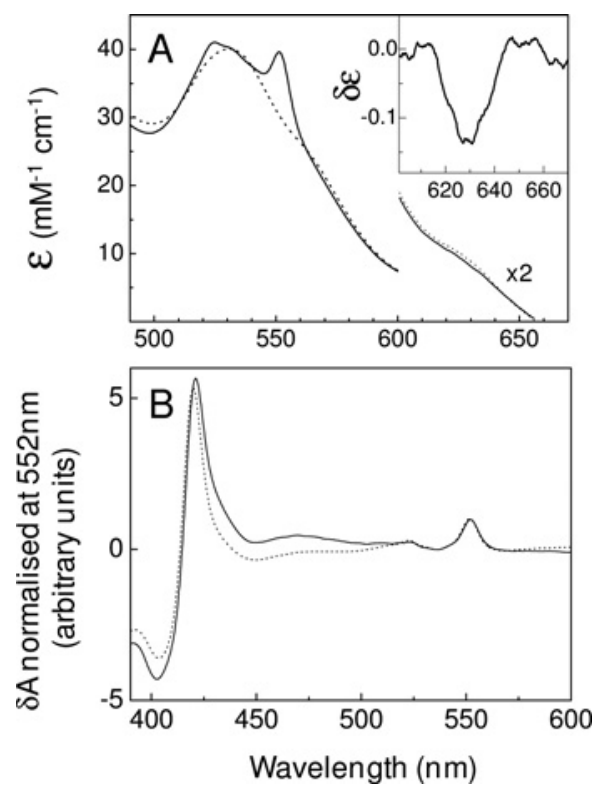

Figure 6 Reduction of CymA by menadiol

(A) Representative electronic absorbance spectra of $4.6 \mu \mathrm{M}$ CymA equilibrated with $7 \mu \mathrm{M}$ menadione and $240 \mu \mathrm{M} \mathrm{NADH}$ (broken line) and 15 min after the addition of diaphorase (solid line). Inset, the difference spectrum, reduced-minus-oxidized, for the charge-transfer band at $628 \mathrm{~nm}$. (B) Representative reduced-minus-oxidized difference spectra for $1 \mu \mathrm{M}$ CymA (solid line) and $1 \mu \mathrm{M}$ CymA with $1 \mu \mathrm{M} \mathrm{FCC}$ (broken line) for the reduction by $100 \mu \mathrm{M} \mathrm{NADH}$, diaphorase and $10 \mu \mathrm{M}$ menadione. In each case the buffer was $20 \mathrm{mM}$ Hepes and $0.5 \mathrm{mM}$ EDTA (pH 7.0) containing $0.05 \%$ DDM.

did not produce any evidence for reduction of CymA. However, CymA reduction was observed when NADH and diaphorase were included in order to provide a greater driving force for the reduction and couple $\mathrm{NADH}$ oxidation to menadione reduction (Figure 6A, solid line). Subsequent addition of dithionite to completely reduce CymA allowed the extent of reduction to be quantified. A $20 \%$ reduction of CymA by NADH was indicated by both the absorbance increase at $552 \mathrm{~nm}$ and the absorbance decrease at $630 \mathrm{~nm}$ corresponding to reduction of low- and highspin haems respectively. Reduced-minus-oxidized difference spectra confirmed the reduction of low-spin haem through the positive features at 420,523 and $552 \mathrm{~nm}$ and reduction of the high-spin haem through the $430 \mathrm{~nm}$ shoulder on the Soret feature (Figure 6B, solid line). The extent of CymA reduction is not changed significantly when the concentrations of NADH and menadione are raised to 2 and $0.5 \mathrm{mM}$ respectively (results not shown).

The extent of CymA reduction by $\mathrm{NADH}$, diaphorase and menadione was also investigated in the presence of the redox partner $\mathrm{Fcc}_{3}$ fumarate reductase that contains four low-spin $c$ haems. The absorbance increase at $552 \mathrm{~nm}$ was used to assess the extent of low-spin haem reduction and the redox difference spectrum to assess reduction of high-spin haem. With the concentration of $\mathrm{Fcc}_{3}$ equal to that of CymA, the increase in absorbance at $552 \mathrm{~nm}$ was $20 \%$ of that achieved for full dithionite reduction of all haems in the sample. The redox difference spectrum showed evidence of a positive shoulder on the Soret feature at $430 \mathrm{~nm}$ confirming reduction of the high-spin haem in CymA against reduction of a relatively larger proportion of low-spin haems owing to the presence of $\mathrm{Fcc}_{3}$ (Figure 6B, broken line). There was no reduction in $\mathrm{Fcc}_{3}$ in the absence of CymA.

\section{DISCUSSION}

The proposed dimer formed by CymA is likely to be stabilized by interprotein interactions mediated by the periplasmic globular domain in addition to the GxxxG motif of the membranespanning helix as described for D. vulgaris $\mathrm{NrfH}$ [16]. However, $S$. oneidensis MR-1 CymA contains 28 more amino acids than $D$. vulgaris $\mathrm{NrfH}$ including 17 more residues between the $\mathrm{CxxCH}$ motifs that bind haems III and IV. This makes it difficult to accurately predict the complete structure of CymA from an alignment-based homology model $[27,46]$. Certainly the MCD of $S$. oneidensis MR-1 CymA provides no evidence for a methionine-ligated penta-co-ordinate haem as found in $\mathrm{NrfH}$. A similar conclusion was drawn from MCD of S. frigidimarina CymA by Richardson and colleagues [26]. In that study, LMCT bands resolved by MCD at near-infra-red wavelengths identified His/His-ligated low-spin ferric haems in the oxidized enzyme. The reduced enzyme displayed positive MCD intensity at $430 \mathrm{~nm}$ alongside a sharp bisignate feature at $552 \mathrm{~nm}$ indicative of highand low-spin ferrous haem respectively. This led the authors to propose that $S$. frigidimarina CymA contained four His/Hisligated ferric haems and that one histidine residue dissociated on reduction of the enzyme. However, and as noted above, the spectral properties of high-spin ferric haem make such centres difficult to detect when their low-spin counterparts are present. Close inspection of the MCD of $100 \mu \mathrm{M}$ oxidized $S$. frigidimarina CymA [26] resolves a broad bisignate feature between 610 and $660 \mathrm{~nm}$ that is indicative of high-spin ferric haem. Consequently, we propose that the CymA enzymes of $S$. frigidimarina and $S$. oneidensis MR-1 have the same haem ligation in all oxidation states, namely, three haems with His/His-ligation and one highspin haem ligated by a nitrogenous amino acid and with either water, hydroxide or a vacancy at the second axial site.

DDM-solubilized oxidized CymA displays an affinity for HQNO $\left(K_{\mathrm{d}} \sim 0.5 \mu \mathrm{M}\right)$ that is comparable with that reported for CymA from Shewanella sp. strain ANA-3 in cytoplasmic membranes [39]. Binding HQNO does not alter the ratio of highto low-spin haems. However, the LMCT band from the high-spin ferric haem shifts to a longer wavelength on HQNO binding that may indicate formation of penta-co-ordinate haem through loss of the water ligand. HQNO binds adjacent to haem I in $\mathrm{NrfH}$ [17] so we consider the high-spin haem of CymA to be haem I. Sequence alignments together with results of site-specific mutagenesis of NapC/NirT family members and the structure of NrfH then allow us to propose amino acid ligands to the CymA haems as follows. Either His ${ }^{50}$, of the first $\mathrm{CxxCH}$ haem-binding motif, or His ${ }^{53}$ will form the nitrogenous ligand to haem I since in D. vulgaris $\mathrm{NrfH}$ it is $\mathrm{Met}^{49}$ rather than $\mathrm{His}^{47}$ of the $\mathrm{CxxCH}$ binding motif that ligates haem I. The low-spin haems II, III and IV would then be ligated by $\mathrm{His}^{79} / \mathrm{His}^{182}$, His $^{140} / \mathrm{His}^{64}$ and His ${ }^{177} / \mathrm{His}^{159}$ respectively, where the first histidine of each pair is that from the $\mathrm{CxxCH}$ motif $[47,48]$. A unified description of $\mathrm{QH}_{2}$ oxidation by haem with a single axial ligand provided by an amino acid may then be appropriate for NapC/NirT homologues.

At $\mathrm{pH} 7$, the midpoint potentials of the CymA haems of approximately $-110,-190,-240$ and $-265 \mathrm{mV}$ were not altered detectably by HQNO binding. This agrees with the results of voltammetric studies of CymA attached to modified gold electrodes [49] and it indicates that HQNO has equal affinity for all oxidation states of CymA. If this situation extends to the descriptions of CymA with $\mathrm{Q}$ and $\mathrm{QH}_{2}$ bound there is a thermodynamic disposition for intraprotein electron transfer from haem I $\left(E_{\mathrm{m}}=-240 \mathrm{mV}\right)$ to the low-spin haems following reduction by $\mathrm{QH}_{2}$ that may serve to minimize the life-time of semi-quinone radicals during $\mathrm{QH}_{2}$ oxidation. That 
CymA is not reduced to any significant extent by menadiol is consistent with the menadione-menadiol couple $\left(E_{\mathrm{m}}\right.$ value of approximately $-80 \mathrm{mV}$ ) having a higher midpoint potential than the CymA haems. Adding the NADH-Q oxidoreductase diaphorase together with a significant excess of $\mathrm{NADH}\left(E_{\mathrm{m}}\right.$ value of approximately $-320 \mathrm{mV}$ ) to increase the reductive driving force leads to reduction of CymA. However, in several repeats of this experiment only $20-30 \%$ of the sample was reduced. There was no indication of rapid interprotein electron transfer that would serve to equilibrate oxidation state across the entire population of CymA in the sample. This is in contrast with the complete reduction of the CymA sample achieved by the addition of excess dithionite or equilibration at $-350 \mathrm{mV}$ by direct, or mediated, electrodic reduction. It must be concluded that the population of CymA behaves heterogeneously when electrons are supplied by menadiol, an analogue of the natural menaquinol substrate, which is presumably oxidized at a specific site in the vicinity of haem I.

No evidence for heterogeneity in the spectral or redox properties of CymA was found when the protein was manipulated electrodically or in HQNO-binding studies. The heterogeneity of the CymA sample with respect to menadiol reduction does though imply that the assays of $\mathrm{QH}_{2}$ oxidation coupled to fumarate reduction underestimate by 4 -fold the rates that may be supported by CymA. Sample heterogeneity is not uncommon in studies of membrane proteins where their separation from lipids and Qs can be extremely difficult to monitor and achieve completely. For CymA it suggests that a co-factor other than haem is required for $\mathrm{QH}_{2}$ oxidation. Elsewhere, we report a voltammetric characterization of CymA that shows a requirement for menaquinol-7 in order for the enzyme to be catalytically active towards menadione [49]. It is possible that in the experiments reported in that paper only a fraction of the purified CymA has a menaquinone- 7 bound and that it is this fraction that is amenable to reduction by menadiol.

Considering these observations in the context of the anaerobic respiratory flexibility displayed by $S$. oneidensis MR-1 several points can be made. We cannot exclude that significantly different $E_{\mathrm{m}}$ values or $\mathrm{QH}_{2}$-binding properties are displayed by CymA in cytoplasmic membranes when compared with DDM micelles; however, this seems unlikely. The majority of the haem-containing globular domain is located in the periplasm and the HQNO-binding properties of DDM-solubilized CymA compare favourably with those displayed by the enzyme in cytoplasmic membranes [39]. Consequently, the redox poise of the menaquinol pool by itself is unlikely to produce significant reduction of CymA. The formal potentials of the $\mathrm{CO}_{2} / \mathrm{HCOO}^{-}$ and $\mathrm{H}^{+} / \mathrm{H}_{2}$ couples in the cell will, like that of the $\mathrm{NAD}^{+} / \mathrm{NADH}$ couple, lie in the vicinity of -300 to $-400 \mathrm{mV}$. Depending on growth conditions, electrons entering the menaquinol pool via the activity of primary dehydrogenases such as the proton-pumping $\mathrm{NADH}$ dehydrogenase or electrogenic formate dehydrogenase and hydrogenase should then provide sufficient driving force to reduce CymA via the menaquinol pool. CymA is not in itself proton-motive, but instead contributes to respiratory energy conversation by recycling the menaquinol pool. Electron transfer from menaquinol to the terminal electron acceptors mediated by the activity of CymA will also be favoured by the thermodynamic bias for that electron transfer, for example the fumarate/succinate couple has a standard reduction potential of approximately -30 $\mathrm{mV}$ at $\mathrm{pH}$ 7. Thus the thermodynamically unfavourable reduction of CymA by menaquinol may be overcome in the cellular context by its integration with an electrical circuitry that can regulate this electron flux at the levels of both electron supply and demand.

In closing we note that the heterogeneity of the CymA sample towards menadiol reduction provided an opportunity to gain insight into the nature of the interaction of CymA and its redox partner $\mathrm{Fcc}_{3}$. Transient interactions were expected to allow a single molecule of CymA to partner different reductases in support of a respiratory plasticity that allows utilization of a wide variety of electron acceptors [50]. However, catalytic reduction of $\mathrm{Fcc}_{3}$ by CymA was not observed. The extent of reduction in samples containing equal quantities of $\mathrm{CymA}$ and $\mathrm{Fcc}_{3}$ was within error of that produced in a parallel experiment lacking $\mathrm{Fcc}_{3}$. The formation of a stable 1:1 complex of the two reduced proteins is suggested. In the cellular context it may be that CymA exists in excess of certain of its periplasmic redox partners such that multiple 'hard-wired' complexes support respiratory flexibility. Experiments are underway to explore the possibilities presented above.

\section{AUTHOR CONTRIBUTION}

Julea Butt developed the project, designed the experiments, analysed the data and wrote the paper; Sophie Marritt led the experimental programme, assisted by Jordon Bye and Thomas Lowe, and contributed to experimental design, data analysis and writing of the paper; Liang Shi, Jim Fredrickson and John Zachara prepared the MR-1 strain overexpressing cymA; Myles Cheesman facilitated MCD and EPR data collection and analysis; Duncan McMillan and David Richardson contributed to the experimental design and data analysis; Julea Butt, Lars Jeuken, David Richardson, Jim Fredrickson and John Zachara secured funding for the project. All authors discussed the results and commented on the paper.

\section{ACKNOWLEDGEMENTS}

We thank Nick Cull for purification of the $\mathrm{FCC}_{3}$ fumarate reductase and Professor James Durrant and Dr Li Xiaoe (Imperial College London, London, U.K.) for the donation of mesoporous nanocrystalline tin dioxide electrodes.

\section{FUNDING}

This work was supported by the U.K. Biotechnology and Biological Sciences Research Council [grant number BB/G009228], the Subsurface Biogeochemical Research (SBR) program/Office of Biological and Environmental Research (BER), the U.S. Department of Energy (DOE), and the Pacific Northwest National Laboratory (PNNL) Scientific Focus Area (operated for the DOE by Battelle under contract DE-AC05-76RLO 1830). D.J.R. was supported by a Royal Society and Wolfson Foundation for a Merit Award Fellowship.

\section{REFERENCES}

1 Fredrickson, J. K., Romine, M. F., Beliaev, A. S., Auchtung, J. M., Driscoll, M. E., Gardner, T. S., Nealson, K. H., Osterman, A. L., Pinchuk, G., Reed, J. L. et al. (2008) Towards environmental systems biology of Shewanella. Nat. Rev. Microbiol. 6, 592-603

2 Hartshorne, R. S., Reardon, C. L., Ross, D., Nuester, J., Clarke, T. A., Gates, A. J., Mills, P. C., Fredrickson, J. K., Zachara, J. M., Shi, L. et al. (2009) Characterization of an electron conduit between bacteria and the extracellular environment. Proc. Natl. Acad. Sci. U.S.A. 106, 22169-22174

3 Bucking, C., Popp, F., Kerzenmacher, S. and Gescher, J. (2010) Involvement and specificity of Shewanella oneidensis outer membrane cytochromes in the reduction of soluble and solid-phase terminal electron acceptors. FEMS Microbiol. Lett. 306, 144-151

4 Coursolle, D., Baron, D. B., Bond, D. R. and Gralnick, J. A. (2010) The Mtr respiratory pathway is essential for reducing flavins and electrodes in Shewanella oneidensis. J. Bacteriol. 192, 467-474

5 Gralnick, J. A., Vali, H., Lies, D. P. and Newman, D. K. (2006) Extracellular respiration of dimethyl sulfoxide by Shewanella oneidensis strain MR-1. Proc. Natl. Acad. Sci. U.S.A. 103, 4669-4674

6 Clarke, T. A., Edwards, M. J., Gates, A. J., Hall, A., White, G. F., Bradley, J., Reardon, C. L., Shi, L., Beliaev, A. S., Marshall, M. J. et al. (2011) Structure of a bacterial cell surface decaheme electron conduit. Proc. Natl. Acad. Sci. U.S.A. 108, 9384-9389

7 Hau, H. H. and Gralnick, J. A. (2007) Ecology and biotechnology of the genus Shewanella. Annu. Rev. Microbiol. 61, 237-258

8 Hunt, K. A., Flynn, J. M., Naranjo, B., Shikhare, I. D. and Gralnick, J. A. (2010) Substrate-level phosphorylation is the primary source of energy conservation during anaerobic respiration of Shewanella oneidensis strain MR-1. J. Bacteriol. 192, 3345-3351 
9 Simon, J., van Spanning, R. J. M. and Richardson, D. J. (2008) The organisation of proton motive and non-proton motive redox loops in prokaryotic respiratory systems. Biochim. Biophys. Acta 1777, 1480-1490

10 Myers, C. R. and Nealson, K. H. (1990) Respiration-linked proton tranlocation coupled to anaerobic reduction of manganese(IV) and iron(III) in Shewanella putrefaciens MR-1. J. Bacteriol. 172, 6232-6238

11 Myers, C. R. and Myers, J. M. (1997) Cloning and sequence of cymA a gene encoding a tetraheme cytochrome $c$ required for reduction of iron(III), fumarate, and nitrate by Shewanella putrefaciens MR-1. J. Bacteriol. 179, 1143-1152

12 Shi, L., Squier, T. C., Zachara, J. M. and Fredrickson, J. K. (2007) Respiration of metal (hydr)oxides by Shewanella and Geobacter: a key role for multihaem c-type cytochromes. Mol. Microbiol. 65, 12-20

13 Schwalb, C., Chapman, S. K. and Reid, G. A. (2003) The tetraheme cytochrome CymA is required for anaerobic respiration with dimethyl sulfoxide and nitrite in Shewanella oneidensis. Biochemistry 42, 9491-9497

14 Gao, H. C., Yang, Z. K., Barua, S., Reed, S. B., Romine, M. F., Nealson, K. H., Fredrickson, J. K., Tiedje, J. M. and Zhou, J. Z. (2009) Reduction of nitrate in Shewanella oneidensis depends on atypical NAP and NRF systems with NapB as a preferred electron transport protein from CymA to NapA. ISME J. 3, 966-976

15 Myers, J. M. and Myers, C. R. (2000) Role of the tetraheme cytochrome CymA in anaerobic electron transport in cells of Shewanella putrefaciens MR-1 with normal levels of menaquinone. J. Bacteriol. 182, 67-75

16 Rodrigues, M. L., Oliveira, T. F., Pereira, I. A. C. and Archer, M. (2006) X-ray structure of the membrane-bound cytochrome $c$ quinol dehydrogenase $\mathrm{NrfH}$ reveals novel haem coordination. EMBO J. 25, 5951-5960

17 Rodrigues, M. L., Scott, K. A., Sansom, M. S. P., Pereira, I. A. C. and Archer, M. (2008) Quinol oxidation by c-type cytochromes: structural characterization of the menaquinol binding site of NrfHA. J. Mol. Biol. 381, 341-350

18 Berks, B. C., Richardson, D. J., Reilly, A., Willis, A. C. and Ferguson, S. J. (1995) The napEDABC gene-cluster encoding the periplasmic nitrate reductase system of Thiosphaera pantotropha. Biochem. J. 309, 983-992

19 Mejean, V., lobbinivol, C., Lepelletier, M., Giordano, G., Chippaux, M. and Pascal, M. C. (1994) TMAO anaerobic respiration in Escherichia coli: involvement of the Tor operon. Mol. Microbiol. 11, 1169-1179

20 Jungst, A., Wakabayashi, S., Matsubara, H. and Zumft, W. G. (1991) The nirSTBM region coding for cytochrome- $c d_{1}$-dependent nitrite respiration of Pseudomonas stutzeri consists of a cluster of monoheme, diheme, and tetraheme proteins. FEBS Lett. 279, 205-209

21 Simon, J., Gross, R., Einsle, 0., Kroneck, P. M. H., Kroger, A. and Klimmek, 0. (2000) A NapC/NirT-type cytochrome $c(\mathrm{NrFH})$ is the mediator between the quinone pool and the cytochrome $c$ nitrite reductase of Wolinella succinogenes. Mol. Microbiol. 35, 686-696

22 Mouncey, N. J., Choudhary, M. and Kaplan, S. (1997) Characterization of genes encoding dimethyl sulfoxide reductase of Rhodobacter sphaeroides 2.4.1(T): an essential metabolic gene function encoded on chromosome II. J. Bacteriol. 179, 7617-7624

23 Rosenbaum, M. A., Bar, H. Y., Beg, Q. K., Segre, D., Booth, J., Cotta, M. A. and Angenent, L. T. (2012) Transcriptional analysis of Shewanella oneidensis MR-1 with an electrode compared to $\mathrm{Fe}(\mathrm{III})$ citrate or oxygen as terminal electron acceptor. PLOS ONE 7, e30827

24 Beliaev, A. S., Klingeman, D. M., Klappenbach, J. A., Wu, L., Romine, M. F., Tiedje, J. A., Nealson, K. H., Fredrickson, J. K. and Zhou, J. (2005) Global transcriptome analysis of Shewanella oneidensis MR-1 exposed to different terminal electron acceptors. J. Bacteriol. 187, 7138-7145

25 Berks, B. C., Richardson, D. J., Robinson, C., Reilly, A., Aplin, R. T. and Ferguson, S. J. (1994) Purification and characterization of the periplasmic nitrate reductase from Thiosphaera pantotropha. Eur. J. Biochem. 220, 117-124

26 Field, S. J., Dobbin, P. S., Cheesman, M. R., Watmough, N. J., Thomson, A. J. and Richardson, D. J. (2000) Purification and magneto-optical spectroscopic characterization of cytoplasmic membrane and outer membrane multiheme $c$-type cytochromes from Shewanella frigidimarina NCIMB400. J. Biol. Chem. 275, 8515-8522

27 Kim, H. J., Zatsman, A., Upadhyay, A. K., Whittaker, M., Bergmann, D., Hendrich, M. P. and Hooper, A. B. (2008) Membrane tetraheme cytochrome $\mathrm{cm}_{552}$ of the ammonia-oxidizing Nitrosomonas europaea: a ubiquinone reductase. Biochemistry 47, 6539-6551

28 Shaw, A. L., Hochkoeppler, A., Bonora, P., Zannoni, D., Hanson, G. R. and McEwan, A. G. (1999) Characterization of DorC from Rhodobacter capsulatus, a c-type cytochrome involved in electron transfer to dimethyl sulfoxide reductase. J. Biol. Inorg. Chem. 274 9911-9914

29 Schwalb, C., Chapman, S. K. and Reid, G. A. (2002) The membrane-bound tetrahaem $c$-type cytochrome CymA interacts directly with the soluble fumarate reductase in Shewanella. Biochem. Soc. Trans. 30, 658-662
30 Firer-Sherwood, M., Pulcu, G. S. and Elliott, S. J. (2008) Electrochemical interrogations of the Mtr cytochromes from Shewanella: opening a potential window. J. Biol. Inorg. Chem. 13, 849-854

31 Myers, C. R. and Myers, J. M. (1993) Role of menaquinone in the reduction of fumarate, nitrate, nitrite, iron(III) and manganese(IV) by Shewanella putrefaciens MR-1. FEMS Microbiol. Lett. 114, 215-222

32 Akagawamatsushita, M., Itoh, T., Katayama, Y., Kuraishi, H. and Yamasato, K. (1992) Isoprenoid quinone composition of some marine Alteromonas, Marinomonas, Deleya, Pseudomonas and Shewanella species. J. Gen. Microbiol. 138, 2275-2281

33 Dobbin, P. S., Butt, J. N., Powell, A. K., Reid, G. A. and Richardson, D. J. (1999) Characterization of a flavocytochrome that is induced during the anaerobic respiration of $\mathrm{Fe}^{3+}$ by Shewanella frigidimarina NCIMB400. Biochem. J. $\mathbf{3 4 2}$, 439-448

34 Shi, L., Lin, J. T., Markillie, L. M., Squier, T. C. and Hooker, B. S. (2005) Overexpression of multi-heme c-type cytochromes. BioTechniques 38, 297-299

35 Shi, L., Chen, B., Wang, Z., Elias, D. A., Mayer, M. U., Gorby, Y. A., Ni, S., Lower, B. H., Kennedy, D. W., Wunschel, D. S. et al. (2006) Isolation of a high-affinity functional protein complex between $\mathrm{OmcA}$ and $\mathrm{MtrC}$ : two outer membrane decaheme $c$-type cytochromes of Shewanella oneidensis MR-1. J. Bacteriol. 188, 4705-4714

36 Berry, E. A. and Trumpower, B. L. (1987) Simultaneous determination of hemes-a, hemes- $b$, and hemes- $c$ from pyridine hemochrome spectra. Anal. Biochem. 161, $1-15$

37 Okun, V. M., Lummen, P. and Brandt, U. (1999) Three classes of inhibitors share a common binding domain in mitochondrial complex I (NADH:ubiquinone oxidoreductase). J. Biol. Chem. 274, 2626-2630

38 Marritt, S. J., Kemp, G. L., Xiaoe, L., Durrant, J. R., Cheesman, M. R. and Butt, J. N. (2008) Spectroelectrochemical characterization of a pentaheme cytochrome in solution and as electrocatalytically active films on nanocrystalline metal-oxide electrodes. J. Am. Chem. Soc. 130, 8588-8589

39 Zargar, K. and Saltikov, C. W. (2009) Lysine-91 of the tetraheme c-type cytochrome CymA is essential for quinone interaction and arsenate respiration in Shewanella sp strain ANA-3. Arch. Microbiol. 191, 797-806

40 Cheesman, M. R., Watmough, N. J., Gennis, R. B., Greenwood, C. and Thomson, A. J. (1994) Magnetic circular dichroism studies of Escherichia coli cytochrome bo: identification of high-spin ferric, low-spin ferric and ferryl [Fe(IV)] forms of heme- 0 . Eur. J. Biochem. 219, 595-602

41 Thomson, A. J., Cheesman, M. R. and George, S. J. (1993) Variable-temperature magnetic circular-dichroism. Metallobiochemistry 226, 199-232

42 Upadhyay, A. K., Petasis, D. T., Arciero, D. M., Hooper, A. B. and Hendrich, M. P. (2003) Spectroscopic characterization and assignment of reduction potentials in the tetraheme cytochrome $c_{554}$ from Nitrosomonas europaea. J. Am. Chem. Soc. 125, 1738-1747

43 Pereira, I. A. C., LeGall, J., Xavier, A. V. and Teixeira, M. (2000) Characterization of a heme $c$ nitrite reductase from a non-ammonifying microorganism, Desulfovibrio vulgaris Hildenborough. Biochim. Biophys. Acta 1481, 119-130

44 Pond, A. E., Sono, M., Elenkova, E. A., Goodin, D. B., English, A. M. and Dawson, J. H. (1999) Influence of protein environment on magnetic circular dichroism spectral properties of ferric and ferrous ligand complexes of yeast cytochrome $c$ peroxidase Biospectroscopy 5, S42-S52

45 Marritt, S. J., van Wonderen, J. H., Cheesman, M. R. and Butt, J. N. (2006) Magnetic circular dichroism of hemoproteins with in situ control of electrochemical potential: 'MOTTLE'. Anal. Biochem. 359, 79-83

46 Murphy, J. N. and Saltikov, C. W. (2007) The cymA gene, encoding a tetraheme c-type cytochrome, is required for arsenate respiration in Shewanella species. J. Bacteriol. 189, 2283-2290

47 Kern, M., Einsle, 0. and Simon, J. (2008) Variants of the tetrahaem cytochrome $c$ quinol dehydrogenase $\mathrm{NrfH}$ characterize the menaquinol-binding site, the haem $c$-binding motifs and the transmembrane segment. Biochem. J. 414, 73-79

48 Cartron, M. L., Roldan, M. D., Ferguson, S. J., Berks, B. C. and Richarson, D. J. (2002) Identification of two domains and distal histidine ligands to the four haems in the bacterial c-type cytochrome NapC; the prototype connector between quinol/quinone and periplasmic oxido-reductases. Biochem. J. 368, 425-432

49 McMillan, D. G. G., Marritt, S. J., Butt, J. N. and Jeuken, L. J. C. (2012) Menaquinone-7 is a specific co-factor in the tetraheme quinol dehydrogenase CymA. J. Biol. Chem., 287, $14215-14225$

50 Firer-Sherwood, M. A., Bewley, K. D., Mock, J. Y. and Elliott, S. J. (2011) Tools for resolving complexity in the electron transfer networks of multiheme cytochromes $c$. Metallomics 3, 344-348 


\section{SUPPLEMENTARY ONLINE DATA}

\section{A functional description of CymA, an electron-transfer hub supporting anaerobic respiratory flexibility in Shewanella}

Sophie J. MARRITT*, Thomas G. LOWE*, Jordan BYE*, Duncan G. G. McMILLAN $\dagger$, Liang SHI¥, Jim FREDRICKSON‡, John ZACHARA $\ddagger$, David J. RICHARDSON*, Myles R. CHEESMAN*, Lars J. C. JEUKEN $\dagger$ and Julea N. BUTT*1

${ }^{*}$ Centre for Molecular and Structural Biochemistry, School of Chemistry and School of Biological Sciences, University of East Anglia, Norwich NR4 7TJ, U.K., † Institute of Membrane and Systems Biology, Centre for Molecular Nanoscience, School of Physics and Astronomy, University of Leeds, Leeds LS2 9JT, U.K., and †tPacific Northwest National Laboratory, Richland, WA 99352, U.S.A.

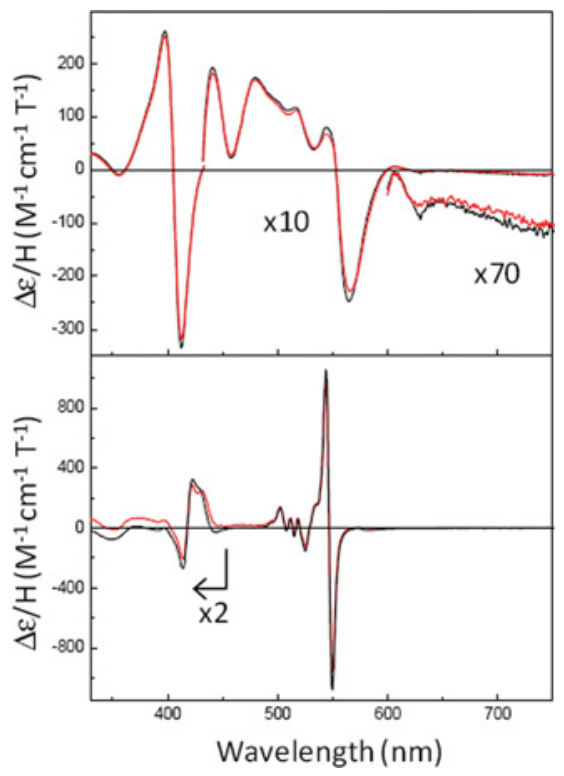

Figure S1 The ambient temperature MCD for CymA in the presence of HQNO

The spectra shown in red are for CymA with a 20-fold excess of HQNO and the spectra shown in black are CymA without added HQNO. Upper panel, isolated $20 \mu \mathrm{M}$ CymA; bottom panel, $10 \mu \mathrm{M}$ CymA fully reduced with dithionite. The buffer conditions were $20 \mathrm{mM}$ Hepes $(\mathrm{pH} 7)$ containing approximately $0.05 \% \mathrm{DDM}$.

\section{Table S1 MALDI-TOF-MS analysis of tryptic digests of CymA}

Listed are the predicted peptides of trypsin-digested CymA which would not contain covalently bound haem and are of detectable size by MALDI-TOF-MS. A total of three out of the four peptides were detected in the excised SDS/PAGE gel band at $24 \mathrm{kDa}$. The most intense absorption at mass 1806.9 Da was detected in excised gel bands at $24 \mathrm{kDa}$ and $50 \mathrm{kDa}$.

\begin{tabular}{llll}
\hline Residues in CymA & Predicted tryptic digest & $\begin{array}{l}\text { Theoretical mass } \\
(\mathrm{Da})[\mathrm{M}+\mathrm{H}]^{+}\end{array}$ & MALDI mass $(\mathrm{m} / \mathrm{z})$ \\
\hline 97-118 & DLYGFLTIDGFNTQAWLDENRK & 2616.27 & 2616.28 \\
193-209 (V5 tag) & LEGKPIPNPLLGLDSTR & 1820.03 & 1820.05 \\
143-157 & IYENQPETMKPMAVR & 1806.89 & 1806.9 \\
$57-68$ & NEVLASAHGGGK & 1139.58 & Not detected \\
& & & \\
\hline
\end{tabular}

Received 1 February 2012/12 March 2012; accepted 29 March 2012

Published as BJ Immediate Publication 29 March 2012, doi:10.1042/BJ20120197

\footnotetext{
1 To whom correspondence should be addressed (email j.butt@uea.ac.uk).
} 